\title{
Pengaruh penerapan model pembelajaran SAVI (Somatic, Auditory, Visual, Intellectual) terhadap kemampuan berpikir kreatif matematis
}

\author{
Sang Ayu Made Monik Kencanawati ${ }^{1 *}$, Sariyasa ${ }^{1}$, I Gusti Nyoman Yudi Hartawan ${ }^{1}$ \\ ${ }^{1}$ Program Studi Pendidikan Matematika, Universitas Pendidikan Ganesha, Singaraja, Indonesia. \\ * Corresponding Author. E-mail: monikkencana26@gmail.com
}

\begin{tabular}{|c|c|}
\hline ARTICLE INFO & ABSTRACT \\
\hline $\begin{array}{l}\text { Keywords: } \\
\text { SAVI, } \\
\text { Kemampuan berpikir } \\
\text { kreatif matematis, } \\
\text { Pembelajaran matematika, } \\
\text { Mathematical creative } \\
\text { thinking abilities, } \\
\text { Mathematical learning. }\end{array}$ & $\begin{array}{l}\text { Mendeskripsikan pengaruh model pembelajaran SAVI (Somatic, Auditory, Visual, Intellectual) } \\
\text { terhadap kemampuan berpikir kreatif matematis siswa adalah tujuan dari penelitian ini. } \\
\text { Penelitian ini merupakan eksperimen semu dengan post-test only control group design. Dari } 436 \\
\text { siswa kelas VII SMP Negeri } 4 \text { Denpasar yang menjadi populasi, dipilih secara acak } 80 \text { siswa } \\
\text { sebagai sampel penelitian. Data kemampuan berpikir kreatif matematis siswa diperoleh melalui } \\
\text { tes uraian yang diberikan kepada siswa di akhir penelitian. Analisis data dilakukan menggunakan } \\
\text { uji- } t \text { satu arah pada dua sampel independen pada taraf signifikan } 5 \% \text {. Berdasarkan hasil analisis } \\
\text { statistik deskriptif diperoleh rata-rata kemampuan berpikir kreatif matematis siswa di kelas } \\
\text { eksperimen sebesar } 62,05 \text { dan rata-rata kemampuan berpikir kreatif matematis siswa di kelas } \\
\text { kontrol sebesar } 53,86 \text {. Hasil pengujian hipotesis menunjukkan bahwa } t_{\text {hitung }}=2,02>t \text { tabel }=1,99 \text {. } \\
\text { Hasil ini menunjukkan bahwa kemampuan berpikir kreatif matematis siswa yang belajar } \\
\text { menggunakan model pembelajaran SAVI lebih baik daripada siswa yang belajar menggunakan } \\
\text { pembelajaran langsung (kelas kontrol). Dengan demikian, dapat disimpulkan bahwa ada } \\
\text { pengaruh dari penerapan model pembelajaran SAVI terhadap kemampuan berpikir kreatif } \\
\text { matematis siswa. Berdasarkan temuan tersebut, penerapan model pembelajaran SAVI di dalam } \\
\text { pembelajaran matematika ini dapat digunakan sebagai alternatif dalam memfasilitasi siswa } \\
\text { untuk mengembangkan kemampuan berpikir kreatif matematisnya. }\end{array}$ \\
\hline
\end{tabular}

Describing the effect of the learning model of SAVI (Somatic, Auditory, Visual, and Intellectual) to the mathematical creative thinking skills of students was the aim of this study. This was a quasiexperimental study with a post-test only control group design. Of 436 seventh grade students of public junior high school (i.e. SMP Negeri 4 Denpasar, Indonesia) who became the population, 80 students were randomly chosen as the sample of this study. Data on mathematical creative thinking skills of the students were obtained from the constructed-response test which was administered at the end of this study. The analysis of data was conducted by using a one-tailed independent samples t-test with a significance level of 5\%. Based on the descriptive statistical analysis we obtained the mean of mathematical creative thinking skills of students in the experimental class was 62.05 and the mean of mathematical creative thinking skills of students in the control class was 53.86. As for the result of hypothesis testing showed that $t_{\text {count }}=2.02>$ $t_{\text {table }}=1.99$. This result implied that the mathematical creative thinking ability of students in the experimental class was better than the mathematical creative thinking ability of students in the control class. Thus, it could be concluded that there was an effect of the implementation of the learning model of SAVI on the mathematical creative thinking skills of students. Furthermore, the implementation of the learning model of SAVI in mathematics learning could be used as an alternative in facilitating students to develop their mathematical creative thinking skills.

This is an open access article under the CC-BY-SA license

\section{How to Cite:}

Kencanawati, S. A. M. N., Sariyasa, S., \& Hartawan, I. G. N. Y. (2020). Pengaruh penerapan model pembelajaran SAVI (somatic, auditory, visual, intellectual) terhadap kemampuan berpikir kreatif matematis. Pythagoras: Jurnal Pendidikan Matematika, 15(1), 13-23. https://doi.org/10.21831/pg.v15i1.33006 


\section{PENDAHULUAN}

Salah satu unsur terpenting yang diperlukan untuk kelangsungan hidup dan berkembangnya suatu bangsa adalah pendidikan. Hal ini karena melalui pendidikan sumber daya manusia dapat ditingkatkan kualitasnya (Arifin \& Retnawati, 2017, p.99). Sumber daya manusia yang unggul, berkualitas, dan berani bersaing adalah hasil dari pendidikan yang baik. Baik atau tidaknya suatu pendidikan dapat tercermin dari kualitas pelaksanaan pembelajaran di sekolah. Pembelajaran yang berkualitas baik tentu setidaknya memenuhi prinsip atau standar proses pelaksanaan pembelajaran sebagaimana yang telah ditetapkan oleh pemerintah guna memfasilitasi siswa dalam mencapai standar kompetensi lulusan yang ada. Dalam Lampiran Standar Proses Pendidikan Dasar dan Menengah (Kemendikbud, 2016) disebutkan bahwa pembelajaran yang terjadi di sekolah seharusnya dapat berupa pembelajaran yang "interaktif, inspiratif, menyenangkan, menantang, memotivasi peserta didik untuk berpartisipasi aktif, serta memberikan ruang yang cukup bagi prakarsa, kreativitas, dan kemandirian sesuai dengan bakat, minat, dan perkembangan fisik serta psikologis peserta didik" (p.1). Dengan demikian, dapat dikatakan bahwa salah satu fokus penting dalam penyelenggaraan pendidikan melalui proses pembelajaran adalah untuk memfasilitasi siswa dalam mengembangkan kreativitasnya, termasuk berpikir secara kreatif.

Banyak ahli menekankan bahwa kreativitas merupakan salah satu aspek penting yang hendak dicapai dalam proses pendidikan. Yazgan-Sag dan Emre-Akdogan (2016, p.26) mengemukakan bahwa mengembangkan kreativitas merupakan hal yang sangat penting di dalam pendidikan. Bahkan menurut Nadjafikhah et al. (2012, p.285) dan Sriraman et al. (2011, p.128), memfasilitasi pengembangan kreativitas seseorang, yang dalam hal ini adalah siswa, haruslah menjadi tujuan dari sistem pendidikan di setiap negara di dunia. Hal ini karena kreativitas diperlukan oleh siswa agar dapat menghadapi berbagai tantangan yang mungkin akan mereka hadapi di masa mendatang secara efisien (Kattou et al., 2013) dan diperlukan ketika membuat suatu pilihan dan keputusan penting di tengah kondisi yang tidak terduga (Sriraman et al., 2011, p.128; Tripathy, 2018, p.4), menyelesaikan suatu konflik atau masalah, dan menghasilkan inovasi (Tripathy, 2018). Oleh karena istilah kreativitas sering digunakan untuk merujuk pada istilah kemampuan berpikir kreatif (Masitoh \& Hartono, 2017, p.221), pada artikel ini, kedua istilah tersebut merujuk pada hal yang sama dan dapat dipergunakan secara bergantian.

Kemampuan berpikir kreatif dan inovatif merupakan salah satu dari empat kemampuan yang perlu dikembangkan oleh siswa di abad-21 ini, di samping kemampuan berpikir kritis dan memecahkan masalah, berkomunikasi, dan berkolaborasi (Trilling \& Fadel, 2009, p.49). Kemampuan ini menurut Trilling dan Fadel (2009, pp.57-58) dapat dikembangkan dengan cara dilatih melalui lingkungan pembelajaran yang bersifat terbuka terhadap gagasan baru dan menyediakan kesempatan untuk belajar dari kesalahan dan kegagalan. Sehubungan dengan hal ini, kemampuan berpikir kreatif siswa dapat difasilitasi melalui penyelenggaraan pembelajaran matematika di sekolah. Ini sesuai dengan tujuan dari pembelajaran matematika itu sendiri. Di Indonesia, salah satu tujuan dari penyelenggaraan pembelajaran matematika di kelas adalah memfasilitasi siswa untuk kreatif, di mana kreatif ini merupakan salah satu kecakapan yang sesuai dengan nilai-nilai yang terkandung di dalam matematika dan pembelajarannya (Kemendikbud, 2014, p.329). Lebih lanjut, pembelajaran matematika, khususnya di tingkat sekolah menengah, diharapkan dapat memfasilitasi siswa untuk melihat matematika sebagai suatu bidang studi yang mempromosikan kreativitas selain sebagai bidang studi yang sangat berguna dan mengasyikkan (NCTM, 2000, p.211).

Mempromosikan kreativitas siswa melalui pembelajaran matematika pada dasarnya tidak terlepas dari pentingnya kreativitas itu sendiri di dalam pembelajaran matematika. Pentingnya kreativitas di dalam pembelajaran matematika, sebagaimana diungkapkan oleh Davis (1984, p.21), didasarkan oleh kenyataan bahwa (1) memfasilitasi siswa dalam belajar matematika dengan menggunakan teknik menghafal saja tidaklah cukup karena cakupan matematika yang luas dan kompleks; (2) sebagian besar siswa akan menemukan dan menggunakan caranya tersendiri ketika memecahkan masalah matematika; (3) guru perlu untuk dapat memberikan tanggapan atas pekerjaan atau ide yang mengejutkan yang mungkin dibuat oleh siswa; (4) memfasilitasi siswa dalam belajar matematika secara kurang bermakna dan dengan cara yang rutin dapat menjadikan siswa kurang termotivasi dalam belajar matematika; (5) terkadang tujuan dari pembelajaran matematika adalah untuk membelajarkan siswa mengenai orisinalitas; dan (6) kreativitas sering diperlukan untuk menerapkan atau menggunakan matematika di dalam kehidupan sehari-hari. Poin keenam yang diungkapkan oleh Davis tersebut sejalan dengan pentingnya kreativitas matematis bagi siswa, yaitu membantu siswa dalam memaknai dan memahami dunia (Idris \& Nor, 2010, p.1963). 
Ada berbagai pendapat mengenai pengertian dan indikator dari kreativitas atau kemampuan berpikir kreatif. Oleh karena itu, konsep kreativitas ini tergolong sebagai suatu konsep yang kompleks atau rumit (Yazgan-Sag \& Emre-Akdogan, 2016, p.27). Secara umum, Trilling dan Fadel (2009, p.59) menyatakan bahwa kemampuan berpikir secara kreatif dapat dipahami sebagai kemampuan siswa untuk dapat (1) menggunakan berbagai teknik yang dapat mengantarkan pada diperolehnya suatu ide; (2) menghasilkan ide yang baru dan berguna; dan (3) memaksimalkan usaha kreatifnya dengan cara mengelaborasi, memperbaiki, menganalisis, dan mengevaluasi idenya sendiri. Serupa dengan pernyataan yang dikemukakan oleh Trilling dan Fadel, Almeida et al. $(2008, p .54)$ mendefinisikan kreativitas sebagai kemampuan dan sikap yang diperlukan untuk membangun gagasan dan produk yang bersifat relatif baru atau orisinal, memiliki kualitas yang tinggi, dan berguna. Dari kedua pernyataan ini, jelas bahwa kemampuan berpikir kreatif juga menjadikan siswa untuk dapat bertindak secara kreatif. Jika dikaitkan dengan matematika, maka kemampuan berpikir kreatif matematis dapat diartikan sebagai kemampuan dalam memformulasikan kembali suatu permasalahan yang bersifat tidak rumit, menemukan dan memaknai solusi dari suatu masalah, dan menemukan metode pemecahan masalah yang bersifat orisinal dari suatu masalah yang tidak biasa (Bishara, 2016, p.3). Lebih lanjut, Laycock (Idris \& Nor, 2010, p.1964) mengartikan kemampuan berpikir kreatif matematis sebagai kemampuan untuk melakukan analisis terhadap masalah matematika yang diberikan dengan berbagai cara, melakukan observasi terhadap pola yang mungkin ada, mengidentifikasi persamaan dan perbedaan, membuat berbagai ide, dan menentukan metode yang tepat untuk memecahkan masalah matematika yang memuat situasi yang tidak biasa.

Kemampuan berpikir kreatif matematis, menurut Shimada (Nohda, 2000, p.45), dapat dinilai berdasarkan banyaknya solusi atas masalah yang ada yang dihasilkan oleh siswa (fluency), banyaknya ide matematis yang berbeda yang dapat ditemukan oleh siswa (flexibility), seberapa orisinalkah ide yang dimiliki oleh siswa (originality), dan seberapa sederhana dan jelaskah ide yang dimiliki oleh siswa tersebut diungkapkan (elegance). Tidak jauh berbeda dengan pernyataan yang diungkapkan oleh Shimada tersebut, Almeida et al. (2008) menyebutkan bahwa kemampuan berpikir tersebut umumnya dinilai berdasarkan empat dimensi dari kemampuan tersebut, yaitu fluency atau kemampuan dalam membuat ide-ide, flexibility atau kemampuan dalam membuat kategori-kategori ide yang berbeda, originality atau kemampuan dalam membuat ide yang tidak biasa, dan elaboration atau kemampuan dalam memaparkan produk secara detail atau rinci. Pendapat yang terakhir inilah yang kemudian digunakan pada penelitian ini sebagai dasar untuk mencirikan dan menilai kemampuan berpikir kreatif matematis siswa.

Pentingnya kemampuan berpikir kreatif, termasuk berpikir kreatif matematis, ternyata tidak dibarengi dengan memuaskannya capaian kemampuan berpikir kreatif siswa yang setidaknya dapat tercermin dari hasil asesmen internasional seperti Programme for International Student Assessment (PISA). Hasil PISA 2018 pada domain matematika, yang pada dasarnya merefleksikan literasi matematika siswa, menunjukkan bahwa capaian skor rata-rata Indonesia hanya sebesar 379 (OECD, 2019b, p.78). Hasil ini tentu merefleksikan literasi matematika siswa yang masih belum memuaskan. Seperti yang kita ketahui, literasi matematis di sini merupakan kemampuan seseorang untuk memformulasikan, menggunakan, dan menginterpretasikan matematika dalam konteks yang beragam (OECD, 2019a, p.75). Dari pengertian literasi matematika ini, jelas dapat dikatakan bahwa literasi matematika berkaitan dengan kemampuan berpikir kreatif seseorang. Dengan demikian, jika literasi matematika seseorang kurang memuaskan, maka hal ini mengindikasikan bahwa kemampuan berpikir kreatif orang tersebut juga kurang memuaskan.

Mengingat pentingnya memfasilitasi siswa dalam mengembangkan kemampuan berpikir kreatif matematis, hasil penelitian Kattou et al. (2013) yang menunjukkan bahwa kemampuan berpikir kreatif matematis memiliki korelasi positif dengan kemampuan matematis, dan belum memuaskannya kemampuan berpikir kreatif siswa berdasarkan hasil penelitian terdahulu, maka perlu dilakukan usaha untuk lebih memfasilitasi siswa, melalui pembelajaran matematika, dalam mengembangkan kemampuan berpikir kreatif matematisnya. Berdasarkan penelitian terdahulu, usaha tersebut dapat berupa mengembangkan perangkat pembelajaran (misalnya, Lutfi, 2019; Masitoh \& Hartono, 2017), menerapkan model pembelajaran tertentu (misalnya, Fitrianawati \& Hartono, 2016; Happy \& Widjajanti, 2014; Rahmi et al., 2019; Rochani, 2016), atau memanfaatkan teknologi pembelajaran (misalnya, Saputra, 2016). Usaha yang umum dilakukan adalah menerapkan model pembelajaran inovatif. Penggunaan model inovatif yang tepat diharapkan dapat digunakan sebagai alternatif dalam usaha untuk memfasilitasi siswa dalam mengembangkan kemampuan berpikir kreatifnya. Pembelajaran inovatif adalah pembelajaran yang digunakan oleh pengajar sebagai salah satu bentuk gagasan yang dinilai baru supaya siswa mendapatkan kemajuan proses dan hasil belajar (Santyasa, 2012, p.90). Banyak model pembelajaran inovatif yang berpotensi dan terbukti 
secara empiris dapat memfasilitasi pengembangan kemampuan berpikir kreatif siswa, salah satunya adalah model pembelajaran SAVI (Somatic, Auditory, Visual, dan Intellectual).

Secara umum, menurut Meier (Sutrisno et al., 2013, pp.662-663), SAVI merupakan model pembelajaran yang mengombinasikan gerakan motorik (fisik), aktivitas intelek, dan mendayagunakan seluruh indra yang dimiliki oleh siswa dalam rangka menyelesaikan permasalahan matematika melalui berpikir kreatif. Secara lebih spesifik, model pembelajaran ini dapat diartikan berdasarkan penyusun dari singkatan SAVI itu sendiri. Berdasarkan pendapat yang dikemukakan oleh Meier (Rahmi et al., 2019, p.1765), Somatic mengandung arti bahwa dalam pembelajaran yang menerapkan model tersebut, materi pembelajaran disajikan kepada siswa dalam usaha untuk memfasilitasi siswa untuk terlibat secara aktif mendayagunakan semua kemampuannya untuk mengajukan pertanyaan dan membangun pengetahuan. Auditory mengandung arti bahwa dalam pembelajaran tersebut, siswa disediakan kesempatan secara maksimal untuk mendengarkan, mengungkapkan pendapat, dan mengajukan pertanyaan apabila ada hal yang belum dipahami. Visual mengandung arti bahwa di dalam pembelajaran yang mengimplementasikan model tersebut, siswa difasilitasi untuk melakukan observasi dan memperhatikan secara visual pada pengetahuan yang sedang mereka bangun. Adapun Intellectual mengandung arti bahwa siswa difasilitasi untuk mendayagunakan kecerdasan atau kemampuan berpikir yang mereka miliki untuk memikirkan dan memecahkan masalah. Oleh karena semua alat indra siswa didayagunakan selama proses pembelajaran yang mengimplementasikan model SAVI, menurut Handoko (2017, p.90), sikap kreatif siswa dapat dikembangkan. Dalam penerapannya, model SAVI ini diimplementasikan menurut tahapan yang dimulai dari tahap persiapan, tahap penyampaian, tahap pelatihan, dan diakhiri dengan tahap penampilan hasil (Khaidir, 2012; Rosalina \& Pertiwi, 2018).

Penelitian sebelumnya telah dilakukan untuk mendeskripsikan pengaruh penerapan model pembelajaran SAVI dalam pembelajaran matematika. Fokus dari penelitian tersebut adalah untuk mengembangkan kemampuan mengonstruksi pemodelan matematis (Khusna \& Heryaningsih, 2018), hasil belajar matematika (Supratman \& Muhlis, 2018), prestasi dan motivasi belajar (Sutrisno et al., 2013), kemampuan komunikasi dan disposisi matematis (Fauziah et al., 2017), dan kemampuan berpikir kreatif matematis (Aprilia et al., 2019; Handoko, 2017; Ramba, 2019). Hasil penelitian yang berfokus pada kemampuan berpikir kreatif matematis telah menunjukkan bahwa penerapan SAVI dalam pembelajaran matematika memiliki dampak positif terhadap kemampuan tersebut pada siswa Sekolah Dasar (SD) (Aprilia et al., 2019), Sekolah Menengah Pertama (SMP) (Ramba, 2019), dan Sekolah Menengah Atas (SMA) (Handoko, 2017). Penelitian yang dilakukan oleh Ramba (2019) tersebut merupakan penelitian tindakan kelas yang pada dasarnya selalu berakhir pada diperolehnya dampak yang positif dari pemberian tindakan yang diimplementasikan. Oleh karena itu, penelitian ini difokuskan untuk memberikan bukti empiris terkait pengaruh pembelajaran SAVI terhadap kemampuan berpikir kreatif matematis siswa melalui penelitian kuantitatif. Dengan demikian, tujuan penelitian ini adalah untuk mendeskripsikan pengaruh dari model pembelajaran SAVI terhadap kemampuan berpikir kreatif matematis siswa, khususnya pada siswa SMP

\section{METODE}

Penelitian ini termasuk ke dalam jenis eksperimen semu dengan desain sederhana, yaitu post-test only control group design. Eksperimen semu dilakukan dengan tujuan untuk mengetahui akibat dari pemberian suatu perlakuan di mana peneliti tidak mengontrol semua variabel dan kondisi eksperimen secara ketat (Sugiyono, 2012, p.109). Dalam penelitian ini, kelas yang diberi perlakuan merupakan kelas yang di dalamnya diterapkan model pembelajaran SAVI untuk memfasilitasi siswa belajar, sedangkan kelas yang tidak diberi perlakuan di dalamnya diterapkan model pembelajaran konvensional (ekspositori). Seluruh siswa kelas VII di SMP Negeri 4 Denpasar tahun ajaran 2019/2020 sebagai populasi. Kelas VII di SMP Negeri 4 Denpasar tersebar menjadi 11 kelas yakni kelas VII-1 sampai dengan VII-11 dengan total siswa sebanyak 436 siswa. Pemilihan sampel dilakukan secara acak di mana kelas VII 9 terpilih sebagai kelas yang diberi perlakukan (kelas eksperimen) dan kelas VII 8 terpilih sebagai kelas yang tidak diberi perlakuan (kelas kontrol) di mana pada masing-masing kelas terdapat 40 siswa.

Penelitian ini dilaksanakan mulai tanggal 13 Februari 2020 sampai tanggal 18 April 2020. Tahapan penelitian yang dilakukan terdiri atas beberapa tahap. Tahap pertama yaitu persiapan, di mana pada tahap ini peneliti menentukan sekolah tujuan, menentukan sampel penelitian, melakukan uji kesetaraan, menentukan materi dan mempersiapkan kelengkapan pembelajaran yang nantinya digunakan selama kegiatan pembelajaran. Setelah itu, peneliti mengembangkan Rencana Pelaksanaan Pembelajaran (RPP) dan Lembar Kegiatan Siswa (LKS) untuk kedua kelas, menyusun kisi-kisi instrumen tes berbentuk uraian yang diberikan kepada siswa sebagai posttest. Sebelum digunakan, terlebih dahulu dilakukan expert judgment oleh dua pakar guna memperoleh instrumen yang ber- 
PYTHAGORAS: Jurnal Pendidikan Matematika, 15 (1), 2020 - 17

Sang Ayu Made Monik Kencanawati, Sariyasa, I Gusti Nyoman Yudi Hartawan

kualitas baik. Tahap kedua yaitu pelaksanaan, di mana pada tahap ini pembelajaran dilaksanakan sesuai dengan rancangan dan RPP yang sudah disiapkan dan pada akhir penelitian dilakukan posttest pada kelas eksperimen dan kelas kontrol. Tahap ketiga yaitu pengolahan data kemampuan berpikir kreatif siswa dengan mengacu pada rubrik penilaian seperti pada Tabel 1.

Tabel 1. Rubrik kemampuan berpikir kreatif matematis

\begin{tabular}{lcl}
\hline Indikator & Skor & Keterangan \\
\hline Kelancaran & 4 & Memberi satu jawaban relevan dengan penyelesaian lengkap, jelas, dan benar \\
& 3 & $\begin{array}{c}\text { Memberi sebuah jawaban relevan, perhitungan benar tetapi penyelesaian kurang leng- } \\
\text { kap atau ide kurang jelas }\end{array}$ \\
& 2 & Memberi satu jawaban relevan, namun penyelesaian dan perhitungan salah \\
& 1 & Memberi sebuah jawaban yang tidak relevan \\
\hline Fleksibilitas & 4 & Tidak memberi jawaban \\
(flexibility) & 3 & Memberi jawaban lebih dari satu (beragam) dan penyelesaian lengkap, jelas, dan benar \\
& & hasilnya terdapat kesalahan namun terdapat kekeliruan dalam menghitung sehingga \\
& 2 & Memberi jawaban dengan satu cara atau lebih penyelesaian dan hasil benar \\
& 1 & Memberijawaban satu cara atau lebih tetapi penyelesaiannya salah \\
\hline Keaslian & 4 & Tidak memberi jawaban \\
(originality) & 3 & Memberi jawaban unik atau tidak biasa serta penyelesaian dan hasil benar \\
& & hitung jawaban unik atau tidak biasa namun hasil salah karena keliru saat meng- \\
& 2 & Memberi jawaban kurang unik atau sudah umum serta penyelesaian dan hasil benar \\
& 1 & Memberi jawaban kurang unik atau sudah umum serta penyelesaian dan hasil salah \\
& 0 & Tidak menjawab atau memberikan jawaban yang tidak relevan \\
\hline Elaborasi & 4 & Menjawab secara rinci dan benar \\
(elaboration) & 3 & Terdapat kesalahan dalam jawaban dan merincinya secara detail \\
& 2 & Perincian yang kurang detail dan terdapat kekeliruan \\
& 1 & Terdapat kekeliruan dan tanpa disertai perincian \\
& 0 & Tidak memberi jawaban \\
\hline & &
\end{tabular}

Sumber: Bosch (Ismaimuza, 2010, pp.74-75)

Pengolahan data dilakukan untuk menganalisis data kemampuan berpikir kreatif matematis siswa hasil penelitian dan menguji hipotesis yang diajukan serta menginterpretasikan hasilnya. Pengujian hipotesis dilakukan dengan menggunakan uji-t satu arah, diawali dengan uji normalitas data untuk mengetahui apakah data yang terkumpul berasal dari populasi yang berdistribusi normal dan uji homogenitas untuk mengetahui apakah data berasal dari populasi yang memiliki kesamaan ragam. Uji normalitas dilakukan dengan menggunakan uji Lilliefors, sedangkan uji homogenitas dilakukan dengan menggunakan uji $F$. Pengambilan keputusan dalam penelitian ini menggunakan taraf signifikan $5 \%$.

\section{HASIL PENELITIAN}

Rangkuman data kemampuan berpikir kreatif matematis siswa, baik pada kelas yang diberi perlakuan (kelas eksperimen) maupun pada kelas yang tidak diberi perlakuan (kelas kontrol), disajikan pada Tabel 2. Berdasarkan Tabel 2, rata-rata nilai kemampuan berpikir kreatif matematis siswa di kelas yang diberi perlakuan lebih baik daripada rata-rata nilai kemampuan berpikir kreatif matematis siswa di kelas yang tidak diberi perlakuan. Lebih lanjut, simpangan baku nilai-nilai kemampuan berpikir kreatif matematis siswa di kelas yang diberi perlakuan lebih kecil dibandingkan dengan simpangan baku nilai-nilai kemampuan berpikir kreatif matematis siswa di kelas yang tidak diberi perlakuan. Dengan demikian, dapat kita katakan bahwa secara deskriptif kemampuan berpikir kreatif matematis siswa di kelas yang mengimplementasikan model pembelajaran SAVI lebih baik daripada kemampuan berpikir kreatif matematis siswa di kelas yang mengimplementasikan model pembelajaran konvensional. 
Tabel 2. Deskripsi kemampuan berpikir kreatif matematis siswa

\begin{tabular}{lcc}
\hline \multirow{2}{*}{ Statistik } & \multicolumn{2}{c}{ Kelas } \\
\cline { 2 - 3 } & Eksperimen & Kontrol \\
\hline$N$ & 40 & 40 \\
Rata-rata & 62,05 & 53,86 \\
Simpangan baku & 16,41 & 19,72 \\
\hline
\end{tabular}

Sebelum uji hipotesis dilakukan, terlebih dilakukan uji prasyarat terhadap data kemampuan berpikir kreatif siswa yang terdiri atas uji normalitas dan uji homogenitas. Melalui uji Lilliefors dengan $N=40$ dan taraf signifikansi $5 \%$, pada kelas eksperimen diperoleh hasil bahwa $L_{\text {hitung }}=0,09<L_{\text {tabel }}=0,14$ dan pada kelas kontrol diperoleh hasil bahwa $L_{\text {hitung }}=0,06<L_{\text {tabel }}=0,14$. Ini berarti pada kedua kelas tersebut $\mathrm{H}_{0}$ diterima. Dengan kata lain, data kemampuan berpikir kreatif matematis siswa, baik pada kelas eksperimen maupun kelas kontrol, keduanya berasal dari populasi yang berdistribusi normal. Selanjutnya, melalui uji $F$ yang dilakukan diperoleh hasil bahwa $F_{\text {hitung }}=1,44<$ $F_{\text {tabel }}=1,70$. Hasil uji $F$ ini menunjukkan bahwa $\mathrm{H}_{0}$ diterima atau data kemampuan berpikir kreatif matematis dari kedua kelas tersebut memiliki ragam yang homogen.

Oleh karena data dari kedua kelas tersebut berasal dari populasi yang berdistribusi normal, uji hipotesis dilakukan melalui statistik parametrik yang berupa uji- $t$ satu arah (one-tailed) pada dua sampel independen. Lebih lanjut, karena asumsi homogenitas ragam terpenuhi, uji-t satu arah yang dilakukan menggunakan asumsi homogenitas tersebut. Hipotesis yang hendak diuji pada penelitian ini adalah kemampuan berpikir kreatif siswa pada kelas yang belajar matematika melalui fasilitas penerapan model pembelajaran SAVI lebih baik daripada kemampuan berpikir kreatif matematis siswa yang belajar matematika melalui penerapan model pembelajaran konvensional (ekspositori). Berdasarkan uji-t satu arah dengan asumsi ragam homogen dan taraf signifikansi $5 \%$, diperoleh hasil bahwa $t_{\text {hitung }}=2,02>t_{\text {tabel }}=1,99$. Hasil ini mengandung arti bahwa ada bukti yang cukup untuk menolak $\mathrm{H}_{0}$. Dengan kata lain, kemampuan berpikir kreatif matematis siswa dalam pembelajaran yang menerapkan model pembelajaran SAVI, secara signifikan, lebih baik daripada kemampuan berpikir kreatif matematis siswa dalam pembelajaran yang menerapkan model pembelajaran konvensional.

\section{PEMBAHASAN}

Berdasarkan hasil analisis data pengujian hipotesis melalui perhitungan uji-t diperoleh simpulan bahwa kemampuan berpikir kreatif matematis siswa yang belajar matematika di dalam pembelajaran yang menerapkan model pembelajaran SAVI lebih baik daripada siswa yang belajar matematika di dalam pembelajaran yang menerapkan model pembelajaran konvensional. Ini berarti model SAVI memberi pengaruh yang baik terhadap kemampuan berpikir kreatif matematis siswa yang mana temuan ini sejalan dengan hasil dari penelitian yang dilakukan oleh Aprilia et al. (2019) dan Handoko (2017). Hasil ini dapat terjadi dimungkinkan karena kelebihan dari pembelajaran yang menerapkan model pembelajaran SAVI yang dapat menempatkan siswa pada posisi yang selalu siap untuk menggunakan seluruh indra yang dimilikinya selama proses belajar (Aprilia et al., 2019, p.37; Fauziah et al., 2017, p.7). Siswa dilibatkan secara langsung di dalam proses pembelajaran untuk mengaktifkan indra-indranya dan menggunakannya secara lebih efektif. Dengan hal semacam ini, kurangnya daya kreatif siswa dapat diatasi (Handoko, 2017, p.87). Selain itu, dengan dukungan Lembar Kerja Siswa (LKS) yang diberikan juga mendukung dalam meningkatkan keberhasilan untuk mengembangkan kemampuan berpikir kreatif matematis siswa. Ini sejalan dengan penelitian terdahulu (misalnya, Lutfi, 2019; Masitoh \& Hartono, 2017; Soeyono, 2014) di mana salah satu cara yang dapat digunakan untuk memfasilitasi atau mendukung siswa dalam mengembangkan kemampuan berpikir kreatif matematisnya adalah mengembangkan LKS. Lebih lanjut, berdasarkan pengamatan peneliti, penerapan model pembelajaran SAVI dapat mengefektifkan kegiatan belajar dengan orientasi kemampuan berpikir kreatif. Hal ini membuat siswa mempunyai kesempatan menggunakan seluruh indranya dan mendapatkan jawaban atas masalah yang diberikan pada LKS.

Tahap-tahap dari model pembelajaran SAVI juga dimungkinkan untuk dapat mengembangkan kemampuan berpikir kreatif matematis siswa. Tahap pertama dari model pembelajaran SAVI adalah persiapan (preparation). Pada tahap persiapan ini siswa diposisikan agar nyaman dan siap dalam memulai pembelajaran. Hal ini dilakukan dengan cara guru memberikan awalan materi dengan situasi yang dikaitkan dengan kehidupan nyata sehingga siswa lebih mudah untuk membayangkan situasi tersebut. Setelah itu siswa diberikan pertanyaan-pertanyaan awal untuk mengetahui sejauh mana pengetahuan mereka terhadap apa yang hendak mereka pelajari. Pada tahap ini, 
siswa dituntun untuk mengingat kembali apa yang telah dipelajari dan dipahami pada pembelajaran sebelumnya melalui pengajuan pertanyaan oleh guru. Hal ini melatih siswa dalam berpikir secara lancar dan mampu mengomunikasikan tentang apa yang dipahaminya. Usaha yang dilakukan guru semacam ini, menurut Haerudin (2013, p.184), dapat melatih siswa dalam membangun makna dan menyampaikan gagasan mereka secara benar dan jelas sehingga gagasan tersebut menjadi lebih mudah untuk dipahami oleh orang lain. Dengan pemberian pertanyaan, siswa difasilitasi untuk mengungkapkan hal-hal dari kemampuan awal yang dimilikinya dengan menggunakan bahasa mereka sendiri. Tahapan ini dapat memfasilitasi siswa dalam mencapai indikator berpikir kreatif yaitu kelancaran (fluency).

Pada tahap kedua dari model pembelajaran SAVI, yaitu penyampaian (presentation), guru memberikan penjelasan secara singkat, kemudian siswa diberikan kesempatan untuk mengemukakan pendapatnya atau bertanya terkait sesuatu yang kurang dipahami ataupun kendala yang ditemui. Pada tahap ini muncul pertanyaan yang beragam dari siswa dan hal ini membuat siswa yang lain berpikir dan memberikan tanggapan atas pertanyaan atau permasalahan yang muncul dengan cara mengeluarkan gagasan yang telah dikonstruksi pada tahap sebelumnya dan guru membantu meluruskan jawaban dari siswa yang masih keliru. Hal ini sesuai dengan pendapat Hamalik (2004, p.35) yang menyatakan bahwa hal dasar yang wajib dihadirkan dalam proses pembelajaran adalah keaktifan siswa dalam mengajukan pertanyaan. Keaktifan bertanya menghasilkan interaksi aktif antara siswa dan guru atau antar siswa. Interaksi aktif tersebut menjadikan suasana kelas menjadi kondusif dan segar karena siswa dapat menggunakan kemampuannya semaksimal mungkin. Tahap ini dapat memfasilitasi siswa untuk mencapai indikator dari kemampuan berpikir kreatif yaitu keluwesan (flexibility).

Selanjutnya pada tahap ketiga yaitu pelatihan (training), siswa difasilitasi untuk mengerjakan LKS dengan cara diskusi dalam suatu kelompok. Pada saat siswa berdiskusi mengerjakan LKS secara berkelompok tersebut berarti siswa berlatih untuk menyelesaikan persoalan matematika, mendapatkan bukti, dan mengemukakan alasan atas jawaban yang diberikan dengan cara dikolaborasikan dengan teman pada satu kelompok tersebut. Dengan membentuk siswa dalam kelompok kecil dan memanfaatkan diskusi antar teman dalam kelompok tersebut, menurut Kusumawati $(2014$, p.6), kualitas pembelajaran terbukti dapat ditingkatkan. Indikator dari kemampuan berpikir kreatif yang tercapai dengan adanya diskusi kelompok semacam itu adalah keluwesan dan orisinalitas.

Kemudian pada tahap terakhir, yaitu penampilan (performance), setelah siswa melakukan diskusi dalam kelompok, siswa diberikan kesempatan untuk menyajikan hasil diskusi kelompok tersebut di depan kelas. Hal ini mengakibatkan siswa lain memahami dan menganalisis jawaban dari kelompok yang menyajikan hasil diskusi kelompoknya tersebut dan jika itu tidak sesuai dengan hasil diskusi kelompoknya maka diberikan kesempatan untuk memberikan pertanyaan ataupun tanggapan untuk kelompok penyaji. Pada tahap ini siswa dilatih untuk berani mempresentasikan jawaban dari hasil diskusi kelompoknya dan bertanggung jawab atas jawabannya sendiri. Hasil dari serangkaian kegiatan ini tentunya berakibat pada berkembangnya kemampuan berpikir kreatif yang dimiliki siswa. Memberikan pendapat tentang apa yang sedang dibahas membuat siswa lebih aktif dalam menyelesaikan latihan soal dan juga dapat menumbuhkan kepercayaan diri siswa. Hal ini sejalan dengan pernyataan Fitriyaningsih et al. (2014) bahwa dalam pembelajaran yang menerapkan model pembelajaran SAVI mengajak siswa untuk terlibat langsung dan aktif, yang salah satunya melalui gerakan fisik, di dalam proses pembelajaran tersebut. Gerakan fisik mampu memaksimalkan proses mental yang pada akhirnya dapat membangkitkan kecerdasan yang dimiliki oleh siswa (Fitriyaningsih et al., 2014, p.31). Dengan demikian, dengan mempresentasikan jawaban kelompok di depan kelas dan mempersilakan siswa lain memberikan tanggapan, siswa difasilitasi untuk mencapai indikator orisinalitas dan elaborasi. Melalui penerapan model pembelajaran SAVI dengan empat tahap yang telah dipaparkan tersebut, siswa difasilitasi untuk terbiasa berpikir lebih fleksibel dan tentunya menyelesaikan permasalahan dengan cara yang tidak biasa dengan didukung oleh latihan soal yang bertujuan untuk memantapkan pengetahuan mereka dalam memecahkan permasalahan yang tentunya dengan cara berpikir yang kreatif.

Secara umum, penerapan model pembelajaran SAVI berjalan sesuai rencana. Akan tetapi, pelaksanaan dari model pembelajaran SAVI di kelas tidak terlepas dari kendala yang tidak terduga. Beberapa kendala tersebut sebagai berikut. Pertama, perlu manajemen waktu yang tepat saat persiapan dan pelaksanaan dari pembelajaran yang penerapan model pembelajaran SAVI. Ini terjadi karena kemampuan siswa yang beragam dalam menyelesaikan permasalahan dengan tuntutan berpikir kreatif yang mengharuskan siswa untuk menjawab dengan fleksibel dan lain dari biasanya sehingga diperlukan bimbingan dan bantuan guru. Hal ini juga mengakibatkan waktu yang dibutuhkan untuk menyelesaikan materi pada LKS cukup banyak. Kedua, siswa mengalami kebingungan saat 
pertama kali diterapkan model pembelajaran SAVI ini, karena tuntutan yang telah disebutkan sebelumnya, siswa perlu waktu untuk membiasakan diri. Oleh karena itu, pada tahap awal dibutuhkan upaya lebih keras agar maksud dari penerapan model pembelajaran SAVI ini dapat dipahami dan diterima oleh siswa. Ketiga, ketika perwakilan kelompok menyajikan hasil diskusinya di hadapan siswa lain, siswa terlihat ragu dalam menyampaikan hasil diskusi kelompoknya. Saat awal pertemuan hanya ada beberapa siswa yang mengacungkan tangan untuk bertanya. Meskipun demikian, kendala tersebut dapat diatasi dengan baik. Kendala itu diatasi dengan memberikan batasan waktu dalam mengerjakan LKS agar siswa tidak kekurangan waktu selama kegiatan belajar. Kemudian, saat dimulainya proses pembelajaran, guru kembali menegaskan tahapan yang nantinya dilakukan siswa selama proses pembelajaran dan memberi motivasi pada siswa dengan cara menyisipkan petunjuk berupa pertanyaan dan pernyataan yang memacu siswa untuk lebih aktif dalam tahap diskusi. Selain itu, dengan mewajibkan siswa untuk bertanya, siswa akan lebih terpacu untuk memahami materi dan pada akhirnya mendorong siswa lebih terbiasa dalam mengajukan pertanyaan, dengan harapan pemahaman siswa terhadap materi menjadi lebih baik dan mampu menyelesaikan permasalahan yang ditemukan saat proses pembelajaran berlangsung. Penerapan dari model pembelajaran SAVI yang diiringi dengan perencanaan yang baik mampu memfasilitasi siswa untuk antusias dan aktif selama proses pembelajaran. Pembelajaran tersebut juga mampu memfasilitasi siswa berimajinasi dalam menemukan hal yang lain dari biasanya, sehingga dapat membentuk kemampuan berpikir kreatif siswa (Handoko, 2017, p.94).

Terjadinya peningkatan kemampuan berpikir kreatif dengan menerapkan model SAVI tidak luput dari kerja sama yang baik antara guru dan peneliti. Dengan mencatat kendala yang dihadapi saat proses pembelajaran pada setiap pertemuan, akan menjadi acuan bagi guru dan peneliti untuk melakukan perbaikan-perbaikan yang akan digunakan sebagai bahan refleksi dan evaluasi untuk pelaksanaan kegiatan pembelajaran berikutnya. Pada proses pembelajaran dengan model SAVI, peran guru sebagai mediator dan fasilitator dalam proses pembelajaran, sementara siswa didorong agar aktif berpartisipasi dan kreatif dalam belajar yang diawali dengan mencari solusi dari sebuah permasalahan, diskusi kelompok, sampai dengan presentasi hasil diskusi. Akibatnya siswa akan terbiasa untuk mengintegrasi pengetahuan baru dengan bantuan pengetahuan yang telah dimiliki sebelumnya. Secara bertahap kemampuan berpikir kreatif pada kelas yang diberi perlakuan berupa pembelajaran SAVI mengalami perkembangan yang lebih baik dibandingkan siswa pada kelas yang diberi perlakuan lain.

\section{SIMPULAN}

Pembelajaran SAVI terbukti memberi pengaruh yang lebih baik kepada siswa, jika dibandingkan dengan pembelajaran konvensional (ekspositori). Melalui pembelajaran SAVI, siswa terbiasa menyelesaikan masalah yang menuntut banyak solusi dan tak biasa, sesuai dengan apa yang sudah dikerjakan sebelumnya. Hal tersebut berimplikasi pada peningkatan kemampuan berpikir kreatif matematis siswa. Berdasarkan uraian tersebut, dapat disimpulkan bahwa penerapan model SAVI memberi pengaruh positif terhadap kemampuan berpikir kreatif matematis. Berdasarkan temuan tersebut, model pembelajaran SAVI dapat digunakan sebagai salah satu alternatif model pembelajaran untuk meningkatkan atau mengembangkan kemampuan berpikir kreatif matematis siswa. Peneliti juga menyarankan kepada peneliti lain agar dilakukan penelitian serupa pada jenjang pendidikan lainnya. Selain itu, pelibatan populasi yang lebih luas sangat disarankan untuk penelitian di masa yang akan datang. Hal tersebut diharapkan dapat memperkuat temuan penelitian ini dan generalisasi yang lebih luas terkait dampak pembelajaran SAVI bagi pembelajaran matematika.

\section{DAFTAR PUSTAKA}

Almeida, L. S., Prieto, L. P., Ferrando, M., Oliveira, E., \& Ferrándiz, C. (2008). Torrance test of creativethinking: The question of its construct validity. Thinking Skills and Creativity, 3(1), 53-58. https://doi.org/10.1016/j.tsc.2008.03.003

Aprilia, S., Sutisnawati, A., \& Amalia, A. R. (2019). Pengaruh model Somatic, Auditory, Visual, Intellectual (SAVI) terhadap kemampuan berpikir kreatif matematis di sekolah dasar. Caruban: Jurnal IImiah IImu Pendidikan Dasar, 2(1), 24-39. https://doi.org/10.33603/.v2i1.2245

Arifin, Z., \& Retnawati, H. (2017). Pengembangan instrumen pengukur higher order thinking skills matematika siswa SMA kelas X. Pythagoras: Jurnal Pendidikan Matematika, 12(1), 98-108. https://doi.org/10.21831/pg.v12i1.14058

Bishara, S. (2016). Creativity in unique problem-solving in mathematics and its influence on motivation for learning. Cogent Education, 3(1), 1-14. https://doi.org/10.1080/2331186X.2016.1202604 
PYTHAGORAS: Jurnal Pendidikan Matematika, 15 (1), 2020 - 21

Sang Ayu Made Monik Kencanawati, Sariyasa, I Gusti Nyoman Yudi Hartawan

Davis, R. B. (1984). Learning mathematics: The cognitive science approach to mathematics education. Ablex Publishing.

Fauziah, F., Winarti, W., \& Kartono, K. (2017). Keefektifan pembelajaran SAVI pada pencapaian kemampuan komunikasi dan disposisi matematis siswa kelas VIII. Unnes Journal of Mathematics Education, 6(1), 1-9. https://doi.org/10.15294/ujme.v6i1.9579

Fitrianawati, M., \& Hartono, H. (2016). Perbandingan keefektifan PBL berseting TGT dan GI ditinjau dari prestasi belajar, kemampuan berpikir kreatif dan toleransi. Jurnal Riset Pendidikan Matematika, 3(1), 55-65. https://doi.org/10.21831/jrpm.v3i1.9684

Fitriyaningsih, F., Jamzuri, J., \& Rahardjo, D. T. (2014). Penerapan pendekatan Somatic, Auditory, Visual, Intellecualy (SAVI) untuk meningkatkan motivasi dan hasil belajar fisika siswa kelas XI di SMA Negeri 3 Boyolali tahun pelajaran 2012/2013. Jurnal Pendidikan Fisika, 2(2), 30-34. https://jurnal.fkip.uns.ac.id/index.php/pfisika/article/view/4674/3213

Haerudin, H. (2013). Pengaruh pendekatan SAVI terhadap kemampuan komunikasi dan penalaran matematik serta kemandirian belajar siswa SMP. Infinity, 2(2), 183-193. https://doi.org/10.22460/infinity.v2i2.34

Hamalik, O. (2004). Proses belajar mengajar. Bumi Aksara.

Handoko, H. (2017). Pembentukan keterampilan berpikir kreatif pada pembelajaran matematika model SAVI berbasis discovery strategy materi dimensi tiga kelas X. Eduma: Mathematics Education Learning and Teaching, 6(1), 85-95. https://doi.org/10.24235/eduma.v6i1.1711

Happy, N., \& Widjajanti, D. B. (2014). Keefektifan PBL ditinjau dari kemampuan berpikir kritis dan kreatif matematis, serta self-esteem siswa SMP.Jurnal Riset Pendidikan Matematika, 1(1), 48-57. https://doi.org/10.21831/jrpm.v1i1.2663

Idris, N., \& Nor, N. M. (2010). Mathematical creativity: Usage of technology. Procedia - Social and Behavioral Sciences, 2(2), 1963-1967. https://doi.org/10.1016/j.sbspro.2010.03.264

Ismaimuza, D. (2010). Kemampuan berpikir kritis dan kreatif matematis siswa SMP melalui pembelajaran berbasis masalah dengan strategi konflik kognitif [Master's thesis, Universitas Pendidikan Indonesia]. Repository Indonesia University of Education. http://repository.upi.edu/8521/

Kattou, M., Kontoyianni, K., Pitta-Pantazi, D., \& Christou, C. (2013). Connecting mathematical creativity to mathematical ability. ZDM - International Journal on Mathematics Education, 45(2), 167-181. https://doi.org/10.1007/s11858012-0467-1

Kemendikbud. (2014). Pedoman Mata Pelajaran Umum Matematika Sekolah Menengah Atas/Madrasah Aliyah (Lampiran III Peraturan Menteri Pendidikan dan Kebudayaan Republik Indonesia Nomor 59 Tahun 2014 tentang Kurikulum 2013 Sekolah Menengah Atas/Madrasah Aliyah).

Kemendikbud. (2016). Lampiran Peraturan Menteri Pendidikan dan Kebudayaan Nomor 22 Tahun 2016 tentang Standar Proses Pendidikan Dasar dan Menengah.

Khaidir, C. (2012). Pembelajaran matematika dengan model SAVI berorientasi PAKEM. Ta'dib, 15(1), 51-60. https://doi.org/10.31958/jt.v15i1.217

Khusna, H., \& Heryaningsih, N. Y. (2018). The influence of mathematics learning using SAVI approach on junior high school students' mathematical modelling ability. Journal of Physics: Conference Series, 948(1), 1-4. https://doi.org/10.1088/1742-6596/948/1/012009

Kusumawati, S. W. (2014). Penerapan model pembelajaran SAVI untuk meningkatkan keterampilan pemecahan masalah di Sekolah Dasar. Jurnal Penelitian Pendidikan Guru Sekolah Dasar, 2(2), 1-10. https://jurnalmahasiswa.unesa.ac.id/index.php/jurnal-penelitian-pgsd/article/view/10583

Lutfi, A. (2019). Pengembangan perangkat pembelajaran menggunakan problem solving dalam problem posing berbasis pendekatan saintifik. Jurnal Riset Pendidikan Matematika, 6(1), 27-38. https://doi.org/10.21831/jpm.v6i1.10231 
Masitoh, L. F., \& Hartono, H. (2017). Pengembangan perangkat pembelajaran matematika dengan pendekatan PBL berorientasi pada kemampuan berpikir kreatif dan self-efficacy. Pythagoras: Jurnal Pendidikan Matematika, 12(2), 220-230. https://doi.org/10.21831/pg.v12i2.15769

Nadjafikhah, M., Yaftian, N., \& Bakhshalizadeh, S. (2012). Mathematical creativity: Some definitions and characteristics. Procedia-Social and Behavioral Sciences, 31(1), 285-291. https://doi.org/10.1016/j.sbspro.2011.12.056

NCTM. (2000). Principles and standards for school mathematics. Author.

Nohda, N. (2000). Teaching by open-approach method in Japanese mathematics classroom. Proceedings of the 24th Conference of the International Group for the Psychology of Mathematics Education, Volume 1, pp. 3953. https://files.eric.ed.gov/fulltext/ED466736.pdf

OECD. (2019a). PISA 2018 assessment and analytical framework. OECD Publishing. https://doi.org/10.1787/b25efab8en

OECD. (2019b). PISA 2018 results (volume I): What students know and can do. OECD Publishing. https://doi.org/10.1787/5f07c754-en

Rahmi, W., Fitria, Y., \& Daharnis, D. (2019). The effect of SAVI model (somatic, auditory, visualization, intellectual) on crative thinking skills based on student learning in IV class in basic school. International Journal of Science and Research (IJSR), 8(1), 1764-1768. https://www.ijsr.net/archive/v8i1/ART20194623.pdf

Ramba, E. (2019). Kreativitas siswa dalam pembelajaran matematika melalui pendekatan SAVI (Somatis, Auditory, Visual dan Intelektual) pada siswa kelas VIII SMP Negeri 1 Rantepao Kabupaten Toraja Utara. Jurnal Pemikiran dan Pengembangan Pembelajaran, 1(1), 117-129. https://doi.org/10.31970/pendidikan.v1i1.35

Rochani, S. (2016). Keefektifan pembelajaran matematika berbasis masalah dan penemuan terbimbing ditinjau dari hasil belajar kognitif kemampuan berpikir kreatif. Jurnal Riset Pendidikan Matematika, 3(2), 273-283. https://doi.org/10.21831/jrpm.v3i2.5722

Rosalina, E., \& Pertiwi, H. C. (2018). Pengaruh model pembelajaran SAVI terhadap kemampuan komunikasi matematika siswa. Jurnal Pendidikan Matematika: Judika Education, 1(2), 119-126. https://doi.org/10.31539/judika.v1i2.313

Santyasa, I. W. (2012). Pembelajaran inovatif. Universitas Pendidikan Ganesha.

Saputra, P. R. (2016). Pembelajaran geometri berbantuan geogebra dan cabri ditinjau dari prestasi belajar, berpikir kreatif dan self-efficacy. Pythagoras: Jurnal Pendidikan Matematika, 11(1), 59-68. https://doi.org/10.21831/pg.v11i1.9680

Soeyono, Y. (2014). Pengembangan bahan ajar matematika dengan pendekatan open-ended untuk meningkatkan kemampuan berpikir kritis dan kreatif siswa SMA. Pythagoras: Jurnal Pendidikan Matematika, 9(2), 205-218. https://doi.org/10.21831/pg.v9i2.9081

Sriraman, B., Yaftian, N., \& Lee, K. H. (2011). Mathematical creativity and mathematics education: A derivative of existing research. In B. Sriraman \& K. H. Lee (Eds.), The elements of creativity and giftedness in mathematics (pp. 119-130). Sense Publishers. https://doi.org/10.1007/978-94-6091-439-3_8

Sugiyono, S. (2012). Metode penelitian pendidikan. Alfabeta.

Supratman, S., \& Muhlis, S. W. (2018). Comparison of learning math learning result students with SAVI model and NHT model on student SMKN 1 Kolaka. Journal of Mathematics Education, 3(1), 22-27. https://doi.org/10.31327/jomedu.v3i1.495

Sutrisno, S., Mardiyana, M., \& Usodo, B. (2013). Eksperimentasi model pembelajaran kooperatif tipe STAD dan TPS dengan pendekatanSAVI terhadap prestasi dan motivasi belajar ditinjau darigaya belajar siswa.Jurnal Elektronik Pembelajaran Matematika, 1(7), 661-671. https://jurnal.fkip.uns.ac.id/index.php/s2math/article/view/3538/2472

Trilling, B., \& Fadel, C. (2009). 21st century skills: Learning for life in our times. Jossey-Bass. 
PYTHAGORAS: Jurnal Pendidikan Matematika, 15 (1), 2020 - 23

Sang Ayu Made Monik Kencanawati, Sariyasa, I Gusti Nyoman Yudi Hartawan

Tripathy, M. (2018). Role of creative thinking as an imperative tool in communication at workplace. Journal of Organizational Culture, Communications and Conflicts, 22(2), 1-7. https://www.abacademies.org/articles/Role-of-creative-thinkingas-an-imperative-tool-1939-4691-22-2-120.pdf

Yazgan-Sag, G., \& Emre-Akdogan, E. (2016). Creativity from two perspectives: Prospective mathematics teachers and mathematician. Australian Journal of Teacher Education, 41(12), 25-40. https://doi.org/10.14221/ajte.2016v41n12.3 